\title{
ОРЧИН УЕИЙН ТӨВ АЗИЙН МАЛ АЖ АХУЙ
}

M.Хурметхан

Төв Ази гэдэг ойлголтонд газарзүйн нэгдмэп байдал, нутаг дэвсгэр, хүн ам, ижил төстэй тап нь япгаанаас давуу байгаа, соёп иргэншил түухийн хувьд ойр дөт байдап, ургамап-амьтны аймгийн ерөнхий төлөв, нийгэм-эдийн засгийн байдлыг харгалзан үзвэп зохих билээ. Өнөөгийн ойлгоптюор газарзуйн хувьд авч үзвэл, Казахстан, Киргизстан, Өзбекстан, Таджикстан, Афганистан, Монгол Улс, ОХУ-ын субъектууд болох Буриад, Тыва, Алтайн ЕНУ, БНХАУын ӨЗО болох Синьцзян, Өвөрмонгоп, Төвдийг оруупсан байдаг юм.

Төв Ази гэдэг ойлголт нь Азийн энэ хэсэгт зориупсан І ерманы нэрт газарзуйч, байгаль судлаач эрдэмтэн А.Гумбольдтын сонгодог бүтээлийн ачаар 19-р зууны хоёрдугаар хагаст шинжлэх ухааны хэлпэгт орж ирэв. А.Гумбольдт уртрагаар Тураны нам тал ба Их Хянганы нурууны хооронд, өргөргөөр Алтайн нуруу, Гимапайн нурууны хоорондох өндөрлөг бэлэнцэг-уулархаг нутгийг Төв Ази гэж нэрлэсэн байна. Хожим нэрт байгапь судлаач Ф.Рихтгофен геопогийн эрт биш үед далайтай холбоогуй болсон Арап ба Каспийн ай савыг оруулаагүй Азийн далайд урсгалгүй мужийг Төв Ази гэж нэрпэхийг саһал болгожээ. Төв Ази нь амьтны газарзуй, геоботаник, хөрс, уур амьсгал, геоморфологи, уупзуйн зэрэг чухал онцлогуудтай ба пандшафтын өвөрмөц хэв шинж нь түүнийг хүрээлсэн мужуудаас эрс япгаж өгсөн байдаг ${ }^{1}$. Өөрөөр хэлбэл, хойд өргөргийн 39.5 хэм ба 49.5 хэмийн хооронд Каспийн тэнгисээс Их Хянганы нуруу хүртэл орон зайг Төв Азид оруулсан анхны тодорхойлоптыг А.Гумбольдт өгсөн байна.

Төв Азийн ОХУ-ын секторт - Өмнөд Сибирийн уулс орно. Өмнөд

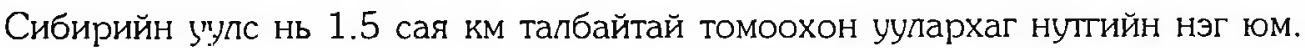
Өмнөд Сибирийн уулархаг мужид Алтай, Кузнешкийн Алатау ба Салаир, Саян, Тыва, Байгаль орчим, Өвер Байгаль, Становын нуруу багтдаг. Уулархаг орны нутагт Буриад, Тыва, Алтайн БНУ, Чита муж бүтнээр, Кемров, Красноярск ба Алтайн хязгаар, Новосибирск, Эрхүу муж, Якутын БНУ-ын зарим хэсэг багтана. Өмнөд Сибирийн уулархаг мужийн хилийн дундаж хур тунадас 300400 мм юм. Хамгийн дулаан 7 сарын дундаж температур нь +19 -радус бөгөөд хамгийн хүйтэн 1 сарын дундаж температур нь -20 градус байдаг. Энд бүх нутгийн 70\%-д цэвдэгт хөрс чупуупаг тархсан байна.

* М.Хурметхан - ОУСХ-гийн эрдэм шинжилгээний тэргучлэх ажилтан доктор (Sc.D), Просфессор 
ОХУ-ын Төв Азийн сектор. ХУснэгт N*1/Малый Атлас СССР.М.1980/

\begin{tabular}{|c|c|c|c|}
\hline $\mathrm{N} \cdot$ & Засаг захиргаа, нутаг дэвсгэрийн хуваарь & $\begin{array}{c}\text { Тапбай \мян. } \\
\text { км.кв }\end{array}$ & $\begin{array}{l}\text { Xун aм } \\
\text { † еag: }\end{array}$ \\
\hline 1. & Буриал БНУ & 351.5 & 1 \\
\hline 2. & Тыва БНУ & 170.5 & 0.3 \\
\hline 3. & Алтайн хязгаар үүнээс: Алтайн БНУ & $\begin{array}{c}261.7 \\
12.9 \\
\end{array}$ & $\begin{array}{l}2.7 \\
0.2 \\
\end{array}$ \\
\hline 4. & Чита & 431.5 & 1.3 \\
\hline 5. & Кемеров & 95.5 & 3 \\
\hline 6. & Эрхүу мужийн баруун өмнөд хагас & 400 & 2.6 \\
\hline 7. & Хакас БНУ & 61.9 & 0.6 \\
\hline 8. & Красгоярскийн хязгаарын өмнөд хэсэг & 140 & 3.2 \\
\hline 9. & Төв Азийн ОХУ-ын сектор & 1817 & 14.7 \\
\hline
\end{tabular}

Тов А.зийн БНХАУ-ын сектор - БНХАУ-ын нутаг нь 3 үнасэн физик газарзүйн мужид хуваагдаж, үүний хоёр нь Төв Азид багтдаг.

Баруун хойд хуурай район: БНХАУ-ын нутгийн 30\%-ийг эзэлж, тариалангийн 10\%, хүн амын 4\% суудаг. Хуурай, хагас хуурай, эх газрын уур амьсгал тод илэрсэн, үндсэндээ бэлчээр гэж үздэг цөл, 山өлөрхөг хээр ба хээрийн ургамалшилтай юм. Ихэнх голууд нь гадагш урсгалгуй дотоодын ай савд багтдаг. Дунджаар далайн түвшнээс дээш 1000-1500 м өндөрт оршино.

Хүйтэғ Альпийн Хөх нуур-Төвдийн район: БНХАУ-ын нутаг дэвсгэрийн $25 \%$-ийг эзэлж, тариапангийн $0.8 \%$, хүн амын $0.8 \%$ оршиж, дунгжаар далайн түвшнээс 40Ј0м өргөгдсөн. Энд мөстпөг, мөсөн гол бүхий 5000-8000м өндөр ер бусын өндөр уулс оршино. Мужийн ихэнх гоп гадагш урсгалгүй дотоодын ай савд багтдаг. Үндсэндээ цөл, хээр, нуга ба бут сөөгөрхөг хэв шинжийн ургамапшилтай. БНХАУ-ын Төв Азийн секторт бэлчээр нуга-319.3 сая га, цөл сэвсүуп, элсэн доорх газар-101.3 сая га, байнгын цастай газар, мөсөн гол-4.7 сая га, өвслєг гүвээ ба хажуу-101.3 сая эзэлнэ².

БНХАУ-Ын Төв Азийн сектор, хуснэгт $N^{*} 2 /$ Энииклопедия нового Китая. M., 1989.c.16/

\begin{tabular}{|c|l|c|c|}
\hline Ne & Мужийн нэр & Тапбай \мян.кв.км\ & Хун ам/сая\% \\
\hline 1 & Хөх нуур \Цинхай\} $&{720} &{4.07} \\
{\hline 2} &{\text { Өвөрмингоп }} &{1183} &{20.07} \\
{\hline 3} &{\text { Ганьсу }} &{450} &{20.41} \\
{\hline 4} &{\text { Синьцязн-Уйгур }} &{1600} &{13.61} \\
{\hline 5} &{\text { Төвд }} &{1220} &{1.99} \\
{\hline} &{\text { Төв Азийн БНХАУ-ын сектор }} &{5173} &{60.1} \\
{\hline}$
\end{tabular}


Төв Азийн баруун хэсэг Казахстан, Дундад Ази нь хапуун хуурай зунтай, өвөл нь цас бага унадаг, харьцангуй хүйтэн өвөлтэй, эх газрын уур амьсгалтай 5үс юм. 7-р сарын дундаж температур нь +25 градус, харин 1-р сарын дундаж температур - 15 градус орчим байна.

Төв Азнйн тусгаар тогтносон БНУ-ууд |хуснэгт N• 3 |

\begin{tabular}{|c|l|c|c|}
\hline N• & Улсын нәр & Талбай /мян.км.кв/ & Хүн ам /сая// / \\
\hline 1 & Казаустан & 2715.1 & 17.3 \\
\hline 2 & Өзбекстан & 449.6 & 21.3 \\
\hline 3 & Туркменстан & 488.1 & 4.6 \\
\hline 4 & Кирг'язстан & 198.5 & 4.5 \\
\hline 5 & Тажикстан & 143.1 & 6 \\
\hline & Төв Азийн БНУ & 3994.4 & 53.7 \\
\hline
\end{tabular}

Монгоп Упс нь Төв Азийн бүс нуттийн зүүн хэсэгт, Ази тивийн зүрхэн талаар орших өвөрмец газарзүйн байрлалтай. Баруунаа Монгол Алтайн нурууны Таван богд уупнаас зүүн тийш Их Хянганы нурууны Соёлз уулс хүртэл 2300 орчим км урт, хойд талдаа Соёны нурууны Монгоп шарын даваанаас урагш Орвог гашууны бор толгой хүртэл 1200 гаруй км үргэ-жлэх 1564.4 мян.Кв.Км нгтаг дэвсгэртэй. Монгоп упсын нутаг үндсэндээ уулархаг бөгөөд хамгийн нам цэг нь далайн түвшнээс 560м өргөгдсөн Их нууруудын хоттор юм. Хагас хуурай уур амьсгаптай, хойд хэсгийн Хөвсгөп, Хангай, Хэнтийн нурууны орчимд ой, тайга бүхий олон гол мөрөн бухий усан сүпжээтэй. Жипд унах хур тунадасны хэмжээ дунджаар 200-220 мм болно. Монгоп орны нутаг дэвсгэрийн 60 орчим хувьд цэвдэгт хөрс чупуулаг тархжээ. Харин хэв шинжийн хувьд тундр-царамын уулын нугын ба нугат хээрийн, уулын хуурай хээрийн, ой тайгын, хар шороон, хүрэн хөрс, бор хөрс зэрэг юм.

Төв Азийн бус нутаг /Хуснэгт $N^{*} 4 /$

\begin{tabular}{|c|c|c|c|c|c|c|}
\hline Ne & $\begin{array}{l}\text { Төв Аз:ийн } \\
\text { сектөрАуд }\end{array}$ & $\begin{array}{l}\text { Талбай } / \\
\text { мян.кB.км/ }\end{array}$ & $\begin{array}{c}\text { Төв Азийн } \\
\text { нутагт эзпзх } \\
\%\end{array}$ & $\begin{array}{l}\text { Хун ам } \\
\text { /сая广 }\end{array}$ & $\begin{array}{c}\text { Төв Азид } \\
\text { әзпэх \% }\end{array}$ & $\begin{array}{c}\text { Хүн амын } \\
\text { нягт хүн/ } \\
\text { км2 }\end{array}$ \\
\hline 1 & Монгол Упс & 1564.4 & $12 \%$ & 2.4 & $1.8 \%$ & 1.5 \\
\hline 2 & $\begin{array}{l}\text { Казахстан, } \\
\text { Дундал Азийн } \\
4 \text { улс }\end{array}$ & 3994.4 & $31 \%$ & 53.7 & $41 \%$ & 13.4 \\
\hline 3 & $\begin{array}{l}\text { БНХАУ-ын } \\
\text { сектор }\end{array}$ & 5173 & $42 \%$ & 60.1 & $46 \%$ & 11.6 \\
\hline \multirow[t]{2}{*}{4} & ОХУ-ын сектор & 1817 & $14 \%$ & 14.7 & $11.2 \%$ & 8.2 \\
\hline & Төв Ази & 12548.8 & $100 \%$ & 130.9 & $100 \%$ & 10.4 \\
\hline
\end{tabular}


Төв Азид бүс нутгийн 6 улс, упс торийн хувьд тусгаар тогтносон нь бус нутгийн 43\%-ийг эзэлж, харин 56\% нь ОХУ, БНХАУ-ын дотоод муж байдлаар оршин тогтнож байна. Төв Ази нь дэлхийн хуурай газрын 23\%-ийг эзэлнэ. Тов Ази нь зөвхөн физик газарзүйн мужлалтыг төдийгүй эрхпэх аж ахуй: /бэлчээрийн мал аж ахуй/, түүх соёл, угсаатны зүй, улс төрийн засаглалыг багтаасан нийгэм эдийн засгичй нийлмэл бүс нутаг болно. Ялангуяа, энэ мап аж ахуйгаас тод томруун харагдана. Төв Ази бол дэлхийн хамгийн уудам бэлчээртэй бүс нутаг болно. Гэхдээ бэлчээрийн даацын хувьд хамгийн сайн нь биш. Төв̈д-Хөх нуурын өндөрлег бсл дэлхийн хамгийн өндөрпөг нутаг төдийгүй 12.3 сая сарлаг бүхий хамгийн сайн бэлчээр юм.

Төв Азийн бэлчээр / хүснэгт N•5/

\begin{tabular}{|c|l|c|c|c|}
\hline N• & \multicolumn{1}{|c|}{ Улс } & $\begin{array}{c}\text { Бэпчээр } \\
\text { сая.га/ }\end{array}$ & $\begin{array}{c}\text { Нийт талбайд } \\
\text { бэлчээрийн эзлэх } \\
\text { хувь }\end{array}$ & $\begin{array}{c}\text { Цэв.Іэгт хөрсийн } \\
\text { эзлэх хувь }\end{array}$ \\
\hline 1 & Монгоп Упс & 125 & $79.9 \%$ & $60 \%$ \\
\hline 2 & $\begin{array}{l}\text { Казахстан ДА-ны 4 } \\
\text { БНУ }\end{array}$ & 213.4 & $53.4 \%$ & $5 \%$ \\
\hline 3 & $\begin{array}{l}\text { Төв Азийн БНХАУ-ьн } \\
\text { сектор }\end{array}$ & 310 & $59.6 \%$ & $35 \%$ \\
\hline 4 & $\begin{array}{l}\text { Төв Азийн ОХУ-ын } \\
\text { сектор }\end{array}$ & 25.4 & $15.5 \%$ & $90 \%$ \\
\hline & Төв Ази & 676.8 & $53.9 \%$ & $34 \%$ \\
\hline
\end{tabular}

Төв Азид 13 сая игіуу сарлаг өсгөн уржуулдгийн 5\% нь Монгоп Улсад, 94\% нь БНХАУ-ын Төв Азийн секторт байна. Мөн Төв Азийн гандуу уулархаг нутгийн ямааны аж ахуй, дэлхийн ноолуурын 90\%-ийг /Моно ол Улс 30\%, БНХАУ 60\%/ өгдег бүс нутаг юм. Төв Азийн БНХАУ-ын сектор нь тус улсын мал аж ахуйч бүтээгдэхуун үйлдвэрлэлийн гоп бүс нутаг юм.

Төв Ази нь олон хүчин зүйлийн, тухайлбал, эдийн засаг, соёп иргэншип, тээврийн гол зангилаа газар болдог нь түүний дэлхий дахины ауч холбогдлыг бий болгож байдаг. Тов Ази нь нүүдлийн соёл иргэншлийн өлгий нутаг юм. Тэгээд ч соёл иргэншилд нь нүүдпийн мал аж ахуйн ач холбогдол их билээ.

\section{Тов Азийн таван хошуу мап, түүний онцлог}

Адууг сүрэг. Төв Азийн нүүдэлчдийн таван хошуу малын ${ }^{3}$ нэг нь адуу юм. Тэд адучгаа мал сүргийн манпай хэмээн хүндэлдэг. Адууг ачаа даах, унааны эдэлгээ, сүу сааль, махыг ашиглана. Мах нь маш чанартай, айраг нь эмчилгээний чухал ач хог:богдолтой.

Адууны үүсэл: 50 сая жилийн тэртээ дэлхийн бөмбөрцгийн хойд хагасын дулаавтар уур амьсгалтай. ус чийг ихтэй ой хөвчид үнэгийн чинээхэн биетэй эогиппус хэмээх амьтан амьдарч байсан нь адууны өвөг байжээ. Цаашдаа тэр 
амьтны дүрс нь өөрчлөгдөн томорсоор 3 хуруутай мерикгиппус, бур сүүпдээ одоогийн алуутай төстэй битүу туурайтай хэд хэдэн салбар адгуус болон хувирчээ. Төв Азид зэрлэгээр оршдог тахь буюу Пржевальскийн адуунаас одоогийн мэнгол адуу үүссэн гэж үздэг. Упмаар хүрэп зэвсгийн үед Европт нутагшсан байна. Адууг гаршуупсан нь Төв Азид барагцаапбал МЭӨ 2-1р мянган жилийн өмно юм. Адуу нь ачааны /владимир г.м/, хөппөх /орпов, орос, американ/, унапга /араб, акаптек. г.м\, тал хээрийн /дон, буденный, монгол, казах г.м/, уулын //кабродин, харабах, киргиз, алтай, азербайжан/, ойт хээрийн /вятка,эстон, якут г.м 200 орчим болж салбарласан байдаг. Төв Азийн нүүдэлчид дээр үеэс адууг сурган ашигласаар иржээ.

Адуун'з ашиг шим: Адуунаас сүү сааль, мах, арьс шир, хөөвор хяпгасыг авч ашиглахаас гадна адууг уналга эдэлгээнд өргөн ашиглана. Сүу сааль: Унагатай гүүг 4-6 сарын хугацаагаар барьж, өдөр 6-8 удаа сааж, нэг гүүнээс дунджаар өдөрт $3 \pi$ сүя авна. Гүуний сүу бол хүний бие махбодод хялбархан шингэдэг уураг, чихэрлэг эрдэс бодис, төрөл бурийн витамин, япангуяа С витаминаар баялаг юм. Сүүгээр нь айраг эсгэнэ. Төв Азийн нүүдэлчдээс Монгол, Казах, Киргизууд адууны сүуг их хэмжээгээр хэрэглэдэг юм. Тэд айраг бэгтгэх өвөрмөц технологийг эзэмшсэн байдаг. Казахуудын айраг бэлтгэх технологийн талаар "Кумыз, Шубат" /А, 1979/ хэмээх номонд тодорхой судлан өгуу Іжээ.

Мах: Төв Азийн адуу, япангуяа, монгол, казах адууны мах нь амт чанартай. Судапгаанагс үзэхэд нас гүйцсэн адуу 280-320 кг амьдын жинтэй, 76\%-ийн цэвэр мах, өөхийн гарцтай. Адууны мах бусад малынхаас илчлэгээр дутуугуй, уургаар баяпаг, идэхэд шингэц сайтай. Казах үндэстний хоол хүнс, заншилд адууны мах тэргүун үүрэг гүйцэтгэнэ ${ }^{4}$.

Арьс г:ир: Адууны арьс шир хэмжээ, чанараараа том үхрийнхээс дутуугуй. Мапчид арьсыг элдэж, ачилга татпагын сур, ширэн эдлэл хийнє. Үйлдвэрийн сайн чанарын хром хийдэг.

Хөөвөр хяпгас: Нэг апуунаас дунджаар 420 гр дэл, 100 гр сүүп, 620гр хөөвөр авна. Эдгээрээс дэл, сүүлээс нь ахуйн хэрэглээний олс бэлтгэнэ.

Уналга эдэлгээ: Төв Азийн нуудэлчид адууг бага наснаас сургаж эхэлнэ. Энэ нь гүу барьж, унага уяхаас эхлэн сургаж, эдэлгээнд бэлтгэн.э. Адууг унаж эдиэхээс гаг:-а тэрэг чарганд хөлпөж, тээвэрт хэрэгпэнэ.

Морин спорт: Төв Азийн нүудэлчид хэзээнээс адууг споръын чиглэлээр өргөн ашиглаж иржээ. Төв Азийн ард түмнүүдийн дунд морин уралдаан өргөн дэлгэрсэн байна. Тэдний дунд хурдан морь шинжих, уях, сойх арга ухаан, уламжлапт ёс заншил ихэд түгжээ ${ }^{5}$.Хурдан хүпгийн тухай ардын домог яриа, туульс өргөн тархсан байдаг. Хурдан морины шинжийг шинжих ард түмэн бүрт өвөрмоц онцлог байх боловч хурдан морины гадар, дотор, нуу山 гэсэн гурван шинжийг гслпоно. Уралдахаас гадна морь уургалах, булгиулах, бугуйлдах, морин дээрээс нум сум харвах, газраас дарцаг шүурэх, саад хагайлгах, казах үндэстэнд “. Кек бөри”, “Кыз куар” зэрэг морин тоглоомын төрөл байна.

Морины тоног хэрэгпэл: адууг унаж эдпэхэд хазаар, чөдөр, .огт, хударга, 
эмээл, ташуур, хомуут, тэрэг, тэрэгний хэрэгсэп, хусуур сойз гэх мэт тоног хэрэгсэп байна. Энд хамгийн чухал зүйл бол эмээл юм. Эмээпийг Төв Азид хэдийнээс Хэрэгпэсэн нь тодорхой бус боловч хаданд эмээптэй морин зургийг зурсан нь олон юм. Эмээп нь монгол, киргиз, казах, орос гэх мэт төрөлд хуваагдана. Казах эмээл гэхэд хийх технологи, зориулалтаас болж олон төрөл байдаг ${ }^{6}$.

Адууны үржип: Түүний хээл авах хугацаа 6-7 сар болно. Гүз 11 сар буюу 340 хоног хээлээ тээдэг буюу энэ хугацаандаа арчилгаа шаардана. Гүүг шүдлэн наснаас 13 нас хүртэл нийлүүпэг оруулна. Зан авир номхон. дөлгөөн, үр төлөөр сайһ удмын бараан хээр, хар, хүрэн зүсмийн азарга тавихыг эрхэмпэлэг бөгөөд азаргыг дэлпэдэггуй. Азарга нь чоно зэргээс сүргээ хамгаалдаг.

Бэпчээр тэжээл: Төв Азид адууг голдуу бэлчээрээр малладаг ба байраар малпах хэсэг ч бий. Адуу бол ямар ч нутагт зохишоо, маплагаанд бага зардал шаарддаг онцлогтой. Малчид адуун сүргийг тухайн нутагтаа зохипуулан маплах нийтпэг арга нийтпэг арга технологийг өөрсдөө сонгоно.

Адуун's нас, шүд: Нас гүйцсэн азарга, морь 40 шүдтэй, ':үдэн шүд-12, соёо-4, араа-24 бол нас гүйцсэн гүу 36 шүдтэй, соёо бараг байхгүй. Төв Азийн нуудэлчид малын шүдний гарц, элэгдлээр насыг нь тодорхойлнс. Монголчууд унага, даага, шүдиэн, үрээ, байдас, хязаалан, соёолон, хавчиг соёопон, гүйцмэп, дор зах гэхчиэн 1-8 насыг нэрлэнэ. Казахууд кулын, тай, кунан, бести, алты, жети, жуан,кари, пахса гэх зэргээр нэрпэнэ.

Адууны зүс: Адуу голдуу хээр, зээрд, хүрэн, бор, хонгор байх нь элбэг юм. Монгол адуу бол судпаачдын бичсэнээр үндсэн 16, давхар 150 зүс байна. Казах адуу боп Г.Грумм-Гржимапогийн бичсэнээр үндсэн 28 зүстэй юм

Адууны явдал: Адуу нь гэлдэргээ, шогшоо, хатираа, цогио, жороо гэсэн үндсэн явдалтай. Казахуудын дунд жороо морь ихээхэн өндер үнэтэй байдаг.

Адуу ба ардын эмчилгээ: Адууны мах сүүг нь эмчилгээнд өргөн ашиглана. Адууны махыг нимгэн зүсэж, хугарсан ясыг бэхжүүпэхэд хэрэглэнэ. Адууны өөх төрөл бүрийн шархыг эдгээнэ. Адууны арьс нь битүү шархыг илааршуулахад, адууны дэлгү нь хавдрыг буупгана. Айраг нь уушги, зүрх, судасны зэрэг өвчинд сайн эм болдог. Ялангуяа, саамыг нүүдэлчид өргөн хэрэглэнэ. Айрагны эмчилгээний талаар судалгаа хийгдэн, эмчилгээний сувипал Монгоп Упс, Казахстанд олон ажиппаж байна. Мөн түүнчлэн казахын ардын эмчилгээнд адууг өргөн ашиглана. Өвчтөнг эмчпэхэд онцгой зус, уүпдэр, насны адууг сонгон ашигладаг байна. Энэ тухай тодорхой жишээг Жанайдарова "Тенгрианство: мифы и легенди древных тюрков" номонд байдаг билээ.

Адуу 5а хэл: Төв Азийн ард тумнуүдийн хэл адуу, түуний анатоми, ашиг шим, мах, сүү, арьс шир, уналга эдэлгээ, зан заншилтай холбоотой нэр томъёогоор нэн баялаг билээ. Тухайлбал, Казах хэлэнд адууны, талаархи нэр томъёог Ш.Жанабилов судлан бичжээ. Үүнд адуун сүрэг, гүҮ, анатоми, унагалах, арчилгаа малпагаа, нас, саах, дэлний онцлог, сүүний гарц, зан авир, дэп сүүпний байдал, өвчин эмгэг, зүйр цэцэн үг гэх мэтээр судпан харуулжээ. ${ }^{8}$ Казах 
хэлний хэльийг И.Кенесбаев судапжээ9 . Монгоп хэлний хувьд Н.Доржготов , Ж.Пувсандорж \нарын бүтээлд тусгалаа опжээ 10.

Aдуу ба тахин шүтпэг: Төв Азийн нүүдэлчдийн ахуй амьдрапд адуу асар чухап үүрэг гүйцэттэжээ. Тиймээс ч тэд адууг дээдпэн шүтдэг юм. МНТ болон туульсын зсхиолд хүпэг морьдын тухай олонтаа өгүүпдэг юм. Тухйалбал, Казахууд олон жип уналгад ашигпасан морио өөрөө муупж, голгойн ясыг байшингийк дээвэр юм уу өндөр орчинд запж дээдэлнэ. Мөн малын дэл сүүпийг авахдаа тогтсон заншлыг дагах ба азаргыг дэлпэдэггуй нь дэл сүүл шиг олон томтой болгох гэсэн санаа юм. Казахууд гүу барихад азаргын магнайд шар тос түрхэж, сүү сааль элбэг болохыг бэлгэднэ. Монголчууд айргийн тавын морийн дэлэнд сүу өргөж хүндэлнэ. Хурдан морины тоногполыг хүндэлж, хупгайлахыг цээрпэнэ. Мэн казахад Ашамай хүүхдийг морь унуупж сургах, камшы /ташуур/, хурим найр, серне ат болон айрагны тапаар олон тооны цагаж мөрдөх заншип байцаг юм.

Тэмээн сүрэг. Төв Азийн таван хошуу малын нэг нь тэмээ юм. Дэлхийд ховрын тоонд ордог тэмээ боп тэсвэртэй, ашиг шим сайтай, сүрлэг сайхан амьтан билээ.

Тэмээний үүсэп: Одоогоос опон арван сая жилийн тэртээ амьдарч байсан туулайн чинээ биетэй пропипопус өорчпөгдсөөр нэг ба хоёр бөхт тэмээ үүсчээ.

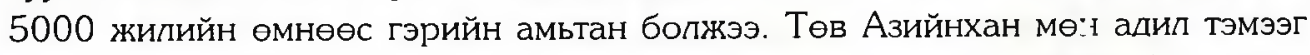
маш эртнээс мал болгож ашиглаж иржээ. Төв Азид хоёр бөхт буюу бактариан тэмээ тархжээ. Төв Азид хоёр бөхт тэмээгээр Монгоп Упс тэргүиж байна. Казахстан 100000 гаруй тэмээтэй байна.Туркменстанд ганц бөхт тэмээ бий.

Тэмээний ашиг шим: Тэмээний ноос, мах, сүу, арьс ширийг авч ашиглахаас гадна уналга эдэлгээнд хэрэглэнэ. Тэмээний ноос онцгой дупаан. хөнгөн, бөх, нэг тэмээ 35-40 наспахдаa 300-480 кг ноос өгнө.

Мах: Тэмээ амьдын жингээр 400-800 кг хүрнэ. Махны амт 'анар сайтай. Тэмээний өөх 55-60кг ба махны өөх 29-33 кг хүрнэ. Тэмээний өох нь сайн чанарын саван, уруупын будаг, нүүрний гоёпын тос хийхэд ашигіана.

Сүү шим: Ингийг саах хугацаа дунджаар 528 хоног үргэпжилдэг өвөрмөц онциогтой км. Өдерт 2-4 п сүү гарна. Нэг ингэ амьдралын туршид 6600-8000л суү өгне. Суү нь удаан гашилдаг, өтгөрех тусам амтлаг болно. Ингэний сүунд гпютаминий хүчип байх туп зарим өвчнийг анагаах чадаптай. Төв Азийнхан тэмээний сүүнээс шубат, чал, хоормог хийнэ. Төв Азийн тэмээний сүүний, бүтцийг нагийвчлан судалжээ ${ }^{11}$. Мөн тэр зохиолд туркмен, казахуудын чал, шубат хийх технопогийг харуулжээ.

Арьс шир: Арьс нь том, чанар сайтай учир хром эдпэл, гутал, хөхүүр, богц, суран эдлэл хийдэг нь түгээмэл юм.

Ачипга уналга: Төв Азийнхан тэмээг ачипга унапганд ашиглаж иржээ. Олон зууны туршид тэмээ нь тээврийн гол хэрэгсэл байсан боловч өнгөрсөн зуунаас хойш ач холбогдоп нь буурчээ. 200 кг ачааг нуруундаа тээх ба 400-600 кГ ачаатай гэрэг чирч 30-60 км явж чадна. Тэмээ урапдуупан шоу зохиодог 
уламжлаптай юм.

Тэмээний үржил: Хоёр жилд нэг удаа ботголох ба хаврын урь орох уед ингэнй: нийлуупэг явагдана. Нэг бууранд 20-30 ингэ гишгуүпэх ба 20 нас хүртэл ашиглана. Хээлээ 13 сар тээж, амьдрах хугацаандаа 10-11 удаа ботголдог байна. .

Тэмээний хариулга, малпагаа: Тэмээн сүргийг эр, эм, сувай, хээлтэй гэх мэт суурилан, улирап, бэлчээрийн байдапд зохицуупан маплана. Багпуур, хамхуул, мууль, шарилж, шаваг, божмог, агь, бударгана, харгана гэх мэт ургамалтай газар бэлчээрлэнэ. Тэмээ маллахад тэмээчний мэдиэг чухал байдаг.

Тэмээчий тоног хэрэгсэл: Эдлэхэд буйл, бурантаг, ногт, тлшаа, хапбар, тохом, хом, ороолт, бамбай, шат, тэрэг гэх мэт тоног орно.

Тэмээний нас шүд: 'Тэмээ 34 шүдтэй. 6 нь доод үудэн шуд, 24 нь араа, 4 нь соёо болно. Төв Азийн нүүдэлчид тэмээг ботго, тором, буйлт, тайлаг, ингэ гэх мэт нас хүйсээр нь ялган нэрлэнэ. Тэмээний төрхийг гол төлөв бөхний нь аяс хэлбэрээр нэрлэнэ.

Тэмээ ба хэл: Төв Азийн ард түмнүудийн хэлэнд тэмээтэй хопбоотой нэр томъёо, зүйр цэцэн үг, хэлц гэх мэт арвин их байна. Тухайлбап, Казах хэлний тэмээний тухай нэр томъёо, хэлЦ үгийг дурдажк бопох байна.Ш.Жанабилов номныхоо 45-79 хуудсанд энэ талаар дэлгэрэнгүй бичсэн билээ. Монгол хэлэнд мөн адил судиагджээ ${ }^{12}$

Тэмээ ба ардын эмчнлгээ: Тэмээний сүу нь нэлээд олон өвчинд эм болно. Шубат, чал, хоормог нь уушигны өвчин болон сульдаа хуүхдэд тустай. Тэмээний ноос нь хавдсан газар, түпэгдсэн, нурууны өвчин, хугарсан ясны хавдарт сайн. Тэмээний уушги нь эмчипгээний чанартай юм.

Тэмээ ба тахин шүтэх заншил: Казахууд зассан буурны ар талын бөхөнд туулайн арьс өлгөнө. Энэ нь зассан буурыг чөтгөр шоолж, ард нь гарна, тэгээд туупайнаас чөтгөр айж халдахгүй гэсэн санаа юм. Шөнө тэмээ үргэвэл гэрээс гарахгүй, учир нь тэмээ өөрөөсөө том амьтнаас $n$ айдаг хэмээн цээриэнэ. Тэмээний топгойг "ноён мап" хэмээн үзэх учир идэхгуй, өндөр газар гаргаж дээдлэн тавина. Тэмээний ноосыг хулгайлан хяргахгүй. Ботгыг алж идэхгүй. Ботгод бурантаг хийхэд хамарт нь нохойн усийг хийдэг нь ботго эсэн мэнд бойжиж, урт наслахыг бэлгэдэж, шар шувууны өд хатгаж хар хэл амнаас сэргийлнэ. Эрт уед хүндрэлтэй төплөж буй малыг “дэмийрсэн” гээд буурыг дэргэд нь авч ирж толгойг нь харуулан дом хийдэг байв.

Yхэр сурэг. Төв Азид боп таван хошуу малын дунд үхэр сүрэг хүндтэй байр эзэлнэ. Мах сүу нь ихээхэн ашиг тусыг өгнө.

Үхрийн үусэл: Суүн тэжээлт, тугапмайт эвэртний язгучрт багтдаг, ац туруут, хивэгч амьтан юм. Манай тооплоос 10-аад мянган жилийн өмнө ухрийг гэрийн тэжээмэл болгожээ. Дэлхийд 400 гаруй үупдрийн ухэр байна. Төв Азид казахын цагдан толгой, монгол үхэр, алатау, сарлаг, хайнаг болог эрлийзэжсэн ухэр тархжээ. Үхрийг мах-суу, суү-мах, махны чиглэлээр өсгөдөг.

Үхрийн ашиг шим, эдэлгээ малпагаа: Үхрээс авч байгаа бүлээгдэхуун бол 
суу, мах, арнс юм. Үнээний сүүний гарц нь тэжээл, арчилгаа, Үүлдэр угсаа, нас гэх мэт олон хүчин зүйлээс шалтгаална. Үхрийн мах бол хүнсний хамгийн үнэт зүйл. Үхрийл махны чанар нь үупдэр, нас, хүйс, тарга хүч зэргээс шалтгаална. Махны калорилог чанар нь тарга тэвээрэг муутайд нь 1200 калори байдаг бол тарганд нь 3000 капори байдаг. Үхрийн шир бол үйпдвэрийн үнэт материап юм. Үхрийн эвэр туруу, цусаар цавуу, цусны гурип зарим төрпийн эмийн бодис хийдэг. Үхрийн маллагаа үндсэндээ нийтпэг түгээмэл байна.

Үхрийн тоноглол: Энэ нь ачаа зөөх, нууж суухад үхрийі шард нуруу ачих, тэрэг хөлпөнө. Энд тусгайлан бэлтгэсэн, ухэр тэрэг, тоноглэл чухал юм.

Үхрийн нас, шүд: Шүд насыг нь шүдээр нь болон эврийн цагирагаар нь тодорхойлдог. 32 шудтэй, учнээс 8 нь үндсэн шуд юм. Насны дагуу тугал, бяруу, гуна, дөнж, шар гэх мэт нэрпэнэ.

Бэлчээр: Үхэр өвсийг хэлээрээ ороож иддэг тул агь, богууль, хиаг, ерхөг, таана, хөмөп், хазаар өвс, шаваг зэрэг ургамалтай бэлчээр тохиромжтой.

Үхэр ба хэл: Үхэр, түуний бие, зан, нас, шуд, өнгө, зан авир зэргийг илэрхийлсэн үгс арвин байна. ${ }^{13}$

Үхэр ба тахин шүтпэг: Казах үхрийн өвөг эцгийг Зенгибаба хэмээн үзэж, үхэр уснаас гарсан гэж төсөөлдөг. Үхэр сүүтэй байхыг эрхэмпэ.э. Заримдаа үхрийг тийм ч магтахгүй. Үхэр ихэрпэхийг муу зүйл хэмээн узэж, хэн түруүпж үзсэн хүн нь ихэр тугапын нэгийг алдаг заншил бий. Үхрийн бөер, хөх, элгийг ндэхгүй. Үхэрд үхрийн цус, сэвсийг үзүулэхийг чээрлэнэ. Үхэр шөнө тугапбап аюупын дохио хэмээн үзнэ.

Үхэр ба ардын эмчилгээ: Үхрийн мах сүуг эмчилгээнд өргөн ашиглана. Хүйтнээс бспсон өвчинд үхрийн сүү өгнө. Мах нь хоолойны өвчинд, хөхүуп ханиаданд сайн.

Хонь: Төв Азид хонины аж ахуй их хөгжжээ. Хонин аж ахуй эдийн засгийн ач хэлбогдлоороо тэргуүн байр эзэлнэ.

Хонины үүсэл: Хонь маш эрт цагт гэрийн тэжээмэл мал болжээ. Хонь опон чүпдэр угсаатай ${ }^{14}$. Үүнээс шалтгаапан ашиг шим, ноос, мах, маплах арга зэрэг нь хоорондоо адилгүй. Бид энд Төв Азийн нэлээд тархсан казах ${ }^{15}$, монгол чүлдрийн ${ }^{16}$ хонины тухай өгүулнэ. Хонины ашиг шим нь их, хонины ус, ноос, мах, суу, арьс зэргийг ашиглана.

Хонины ноос: МТӨ 4500 жилийн өмнөөс нуудэлчин айлууд хонин уртын ноос, ахраар гэрийн бүрээсний эсгий, ширдэг, тохом, урлалын бусад зуйл хийж байжээ. Хонины ноосноос цэмбэ, ноосон даавуу, хивс, малгай, цамц, гэрийн бурээс, эсгий гэх мэт хийнэ.

Хонины мах: Төв Азид хонины махны нядапгааны гарц 54-56 хувь байна. Төв Азийнхан малынхаа мах, сүу, арьс ширийг ашиглах арга ухааны арвин туршиага хуримтпуупжээ. Тухайлбал, хонины махыг эвдэу, мапын мах, яс зэргээр хүндэтгэл илэрхийлэх ёсоор арвин юм. Хамгийн хүндтэй хүндээ монгопчууд хонины ууц чанаж тавьдаг боп казахууд хонины тоггойг хамгийн эрхэм дээд чанартай гэж үнэлэн зочиндоо өгдөг юм. Казахуудад махны үе мөч 
бухэн нэртэн бөгөөд өөрийн хэрэгпэх зориулапттай байна ${ }^{17}$.

Хонины суу: Сүу нь тоспог ихтэй. Төв Азийнхан хонио сааж, сүу авч, төрөл бүрийн хоол хүнс бэлтгэдэг уламжлалтай.

Хонины арьс: Төв Азийн нүүдэпчид хонь өвчих өвөрмөц технопогитой. Тухайлбал, монголчууд өрлөж, казакууд хоолойг огтпон байж мал муулна. Эхлээд арьсыг тодорхой дэс дарааллаар яаран, шар мах оруулхлгүй өвчинө. Өвчсөн арьсыг угааж, хатааж, давслан айраг, тараг түрхэн идээ оруулан эпдэнэ. Элдсэн арьс нь бүтээгдэхүүн хийхэд бэлэн болдог.

Хониңы үржил: Хонин сүргийн үржил нь хушыг зөв сонгохоос эхэлнэ. Энд бие галбир, ноосны гарц, сүүпний янз, удам угсаа, өнгө зус, арьс хөрсөөр нь шилж сонгоно. Хонийг хоёрдугаар сарын сүүлч, 3-р сарын эхээр хургапахаар бодож, хээлтүупэг явуупах нь Төв Азид түгээмэл юм. Нэг хонь нэг жилд 2, 2 жилд-4, 3 жилд-8, 4 жилд-16, 5 жипд-32, 6 жипд- 64,7 жипд-128, 8 жилд-256, 9 жилд-512, 10 жилд- 1024 хонь болж өсдөг юм.

Хониғ.دі бэлчээр: Хонины бэпчээр нь жилийн 4 улирапд төд'ийгүй сар сар, өдөр өдөрт нь өөр байна. Энэ нь өвсний байдал, цаг уур, салхины чиглэл гэх мэт микроцаг уурын нөхцлөс шалттаална. Улирал болгонд хонь маллах технологи өөр өөр байна. Мөн угсаатан бүр, байгалийн бүс гэх мэт онциогтой юм. Газрын гадаргад мал идэж болох ургамал, өвсний тоог эрдэмтэд 800 гэж үздэг. Тэдгээрээс нь хонь 520-ыг иддэг ба тэдгээрээс нь 91 төрлийн агь байдаг, үхэр тэдний зөвхөн 24, адуу 39-ыг нь идлэг бол хонь 46 төрлийг нь иддэг байна. Эндээс хонь бол уян хатан тэжээг. гэй хаана бол хаана бэлчээрлэх боломжтой нь харагдана. Казахуудын уламжилт хонь маллах арга ${ }^{18}$ нь монгопчуудтай төстэй билээ.

Хонины нас шүд: Хонийг монгопчууд хурга, шүдлэн /эр/, төлөг /эм/, хязаалан, зусаг, соёолон гэх мэт, казакууд козы,тогты,тусах, хошхар гэх мэт нэрлэнэ. Хонь 32 шүдтэй, үүдэн шүд 8, араа 24. Нэг сартайд хурганы үүдэн шүд, 9 сартайд нэг, хоёрдугаар араа нь ялгарна. Голын 2 үүдэн шүд нь солигдохыг шүдпэн, дунд 2 уүдэн шүд нь сопигдохыг хязаалан, захын шүд солигдохыг соёолон, шүц жигдрэхийг нас гүйцсэн гэнэ.

Хонь ба хэл: Төв Азийн нүүдэлчдийн хэлэнд хонь, түүнтэй холбоотой нэр томъёо нэн элбэг билээ. Үүпдэр угсаа, биеийн анатоми, хүйс, нас, зүс, саах, нийлүүлэг, ноос, эр, эм, хуџ, ирэг, хурга, зан авир, явдал, эр хонийг засах, им тамга, өвчин түүний эмчпэхтэй тэдгээр хэлний үгсийн сангийН томоохон хэсгийг эзэлнэ. Тухайлбал, Казах хэпэндэх нэр томъёог дурдаж болох юм ${ }^{19}$. Казах хэлээр хонины дагзанд 60, толгойд нь 500 нэр байгаа юм. Монгоп ${ }^{20}$, казах $^{21}$ хэп нь хонь1 й холбоотойг зүйр цэцэн үг, ерөөл гэх мэт нэн элбэг болно.

Хонь ба тахин шүтлэг: Казахууд хонины өвөг дээдэс нь Шопан Ата гэжк нэрлэн хонь диваажингаас гарсан гэж үзнэ. Шөнө хонь майлахыг айх, аюулын шинж хэмээн төсөөлдөг. Өвчин зовпонгоос сэргийлэн хонийг тахиж, тахиупагч цээжээ үнэртүупэн давс өгнө. Хүзүүнд хөгний хэсгийг зүүнэ.Тэл хонийг алж идэхгүй, ядуу зүдүу хунд өгвөл тэр идэж болно. Тэр хонь өөрөө үхвэл сайн гэдэг бөгөод тахигчийн зовпон зүдгүурийг нимгэлсэн гэж үздэг. Хүмүус баярпахдаа, 
айхдаа, ямар нэгэн аюул тупгарахдаа, тэнгэрт запбиран юм хусэхдээ хонь гаргаж, найр хийхийг “ахсарбас" гэдэг юм. Зориуд гаргах мал нь цагаан, цагаан халзан өнгөтэй байх нь аз жаргал, цэвэр ариун байхын бэлгэдэıюм ю22. Ирсэн зочина, хүнд бэлэглэхэд хар зүсмийн хонь байхыг цээрлэнэ. Нядлах хонийг баруун талаас барих ба баяр ёслолд зориулсан хонины гурван хөлийг п бооно. Хонинд халдварт өвчин тусвал оршуупгын газар хонуулж, чонын арьсаар шөнө гурван удаа үргээнэ. Алсын замд явсан хунд зориулан хургыг нэрлэдэг зэрэг опон заншил байна.

Хонь Ја ардын эмнэлэг: Хонины мах сүү нь өвчинг эмчлэх, өвчтөнийг тэнхруүпэхэд өргөн ашиглагдана. Япангуяа, нярайлсан эхэд “кэпжа" хэмээн хонь гаргаж, шинэ шөл уулгах ёсон байна.

Ямаа. Төв Азид ямаан сүрэг өргөн тархсан ба дийлэн: нь БНХАУ, Монгоп Упсад байна. Ямааг гол нь ноолуур, сүуний чиглэлээр ашигпана. Ямааны ноолуур дэлхийн зах зээлд өндөр үнэлэгдэнэ.

Ямааны гарал уүсэл: Эрдэмтэд янгир ямаанаас гэрийн ямаа үүссэн гэж үздэг. Төв Азид МЭӨ 5700 жипд ямааг гэршуупсэн байна. Ямаа нь олон уупдэр угсаатай. Төв Азийн уугууп ямаа өөр хоорондоо болон янгир, Европын ямаатай эрлийзжуулж, ашиг шимийг дээшлуулэх ажил хийжээ. Төв Азийн ямаа мах, суY, ноопуурын чиглэлтэй юм. Гол ашиг шим нь ноопуур, хялгас, зуу, мах, арьс шир юм.

Ноолуур хялгас: Нэг ямаанаас 260 гр ноопуур, мөн төдий хэмжээний хялгас гарна. Ямааг нас, хүйс, цаг уурын байдлаас шалтгаалан харилшан адилгүй хугацаанд симнана. Урт, богино, хол, ойр шүдтэй 3-4 янзын самаар самнадаг.

Сүу: Ямааг өдөрт 1-2 удаа саахад саапийн хугацаанд нэг ямаанаас жилд дунджаар 50л хүртэл сүү ашигпана. Ямааны сүү нь үнээнийхтэй ойропцоо найрлагатай боловч тослог, уургаар баялаг, ипчлэгээр давуу. Кальци, фосфор, витамин ихтэй учир хүний биед шим тэжээл болно.

Мах: Нэг ямаанаас 12-18 кг мах, 2-3 кг өөх авна. Хүнй̆ хооп тэжээп хамгийн гол үзуупэлт болох уургаар баялаг.

Арьс: Төв Азийнхан ямааны арьсаар дупаан хувцас, эдлэл хийнэ.

Үржил төл: Ямаа ур төлөө өгч, үржипд тэншэх нийт хугацаа 7-8 жил. Ишиг хүйтэнд тэсвэрлэхдээ муу, бээрэг учир нилээн дупаарсан үед төлпуулнэ.

Бэлчээр тэжээл: Төв Азийнхан ямаа бэлчээрлүупэх өвөрмөц туршлагатай. Өдөрт дунджаар 9-16 цаг бэлчээрт байна. Агь, шувуун хөз, хөмөл, таана, гөгөд, мангир, хиаг, ерхөг, шарипж мэтийн өвс ургамап иднэ.

Ямааны нас шүд, зус: Ямааг нас, хүйсээр ялган нэрлэнэ.

Ямаа Ја хэл: Ямааг мөн тал бүрээс нь нэрлэсэн нэр томьёо, уран үтс, зүйр цэцэн үг эпбэг. ${ }^{23}$

Ямаа б́a тахин шүтлэг: Ямааны өвөг нь Шекшек Ата, бөгөөд ямааг хад чулуунаас бий болжээ гэж төсөөпдөг. Ямааг хүндэтэх боловч бусад мапын тувшинд авч үзэхгүй. Чөтгөр бол ямаанд дуртай, ямаан дүрстэй байна гэж үзнэ. Тэгээд шөнө ганц ямаа тааралдвал сэжиглэнэ. Нүүдзпчид зочноо 
ямаагаар дайлахыг цээрлэнэ. Тавьтаргүй, тэсвэргүй явдлыг ямаатай зүйрлэнэ. Монгопчууд сэрхийг тахиж, хүзүүнд утас уяж тавина. Малын хймгаалагч гэж үзнэ. Ойрдуудын бөхчүүд ямааны арьсаар зодог шуудаг хийж барипдана.

Ямаа ба ардын эмчилгээ: Ямааны өөхийг түлэгдсэн газар тавина. Ямааны сүуг хөхүул ханиад, сульдаа хүухдэд уулгана. Ямааны өөхийг халуунаар ханиадыг дарахад ууна.

\section{ЭШ/IЭЛ, 3YY}

${ }^{1}$ В.М.Синишын. Центрапьная Азия.М.,1959. с.5-6

2 Энциклопедия нового Китая. М.,1989.с. 12

3 Дэлхийн улс төрийн зургийн бүрдпийн түух, орчин үе. Упаанбаатар, 1999

${ }^{4}$ Radloff.W.W.Die Hausthede der Kirdisenl.Zeithschirift der Ethnofide., Berti1871.Bd.,s:285-313

${ }^{5}$ Казахын үндэстний хоол хүнс. А., 1977.т.33-35

${ }^{6}$ А.Баярмагнай. Монгопчуудын хурдан морь уях соёл, түухэн упамжлап. УБ,1997 "Традиции предков-бесценное сокровиче" А. 1988.с.68-96-д казахуудын хурдан морь уях соёл, түүхэн упамжлапыг өгуүпжээ.

7 "Традиции предков-бесценное сокровице" А. 1988 с.96-113. "БНМАУын угсаатны зүй” Боть-1.,УБ.1987 Боть-2., УБ.1996 Боть-3. УЕ.1996.

${ }^{8}$ Г.Грумм-Гржимайло. Описание путешествия в Западный Китай.Т.1 В доль Восточного Тяньшаньья.с. 430

${ }^{9}$ Жанабилов Казакын мал атаупары А.1982 т.6-44

10 К.С.Кенесбаев.Фразологический споварь казахского языка.А., 1977. б.514-518.

11 Ж.Пувсандорж “Мапчны эрдэм” УБ.1986 Н.Доржготов “АнглиМонгоп, Монгол-Ангпи аж ахуйн дүймэн.УБ., 1999

12 Кумыс и Шубат. А., 1980. с.171-197

${ }^{13}$ Ж.Пувсандорж "Мапчны эрдэм" УБ.1986. т.157-189

14 Ж.Пувсандорж "Малчны эрдэм" УБ.1986.Жанабипов Казахша мал атаупары А. 1982 т.80-97

${ }^{15}$ Ш.Жанабипов Казахша мал атаупары А.1982 т.98-103

${ }^{16}$ Мөг: тэнд

${ }^{17}$ Хүүхэд запуучуудын нэвтэрхий толь. УБ., 1983.т. 121-22

${ }_{18}$ Х.Досымбек. Монголын казахуудын уламжилт хооп хүнс.А., 1996.т.1-21

19 С.Капиев. М.Оразаев. М.Смаипова. Обычай и традиции казахского народа.А., 1994.б.88-99

${ }^{20}$ Ш.Жанабилов Казахша мал атаулары А. 1982 т.98-130

${ }^{21}$ Ж.Пувсандорж “Мапчны эрдэм" УБ. 1986

${ }^{22}$ К.С.Кенесбаев.Фразопогический споварь казахского языка.А., 1977. 6.514-518.

${ }^{23}$ К.Бикумар.Монголиядагы казахтардын салт-дастүрпери.Ө.1995.б.11-136 